\title{
PDE8B Gene
}

National Cancer Institute

\section{Source}

National Cancer Institute. PDE8B Gene. NCI Thesaurus. Code C114556.

This gene plays a role in the metabolism of cyclic AMP. 